Krzysztof ŻĘGOTA

Uniwersytet Warmińsko-Mazurski, Olsztyn

\title{
Liczebność diaspory polskiej w Obwodzie Kaliningradzkim Federacji Rosyjskiej. Zarys problematyki
}

$\mathrm{K}$ westie związane z problematyką diaspory polskiej zamieszkującej kraje byłego Związku Radzieckiego są, zwłaszcza od początku lat 90. XX w., tematem intensywnych badań naukowych ${ }^{1}$. Zainteresowanie naukowców skierowane zostało nie tylko na obszary licznego zasiedlenia przez ludność polską, będącą tam autochtonami, tzn. Litwę, Białoruś i Ukrainę, ale również na te terytoria, gdzie ludność pochodzenia polskiego stanowiła element napływowy. Otworzyły się też możliwości badania diaspory polskiej zamieszkującej Obwód Kaliningradzki Federacji Rosyjskiej, choć należy zaznaczyć, że po 1989 r. prowadzono jedynie wyrywkowe badania dotyczące tej społeczności ${ }^{2}$.

1 Mniejszości polskie i Polonia w ZSRR, pod red. H. Kubiaka, Kraków-Wrocław 1992; Polacy w Kościele katolickim w ZSRR, pod red. E. Walewandera, Lublin 1991; A. Sadowski, Aktualny stan i zadania przyszłe badań nad Polakami na Wschodzie (wprowadzenie do dyskusji), „Przegląd Polonijny” 2001, z. 4, s. 49-58; M. Krzyszycha, V. Sobierańska, Odradzanie się mniejszości polskiej w Federacji Rosyjskiej, Lublin 2003; E. Walewander, Katolicyzm na Wschód od Bugu. Fakty i nadzieje, Nakło n. Notecią 1998; R. Dzwonkowski, Polacy na dawnych kresach wschodnich, Lublin 1994.

2 Przykładem może tu być rozprawa doktorska ks. Stanisława Gorgola Religijność katolików w środowisku wielkomiejskim. Studium socjologiczne na przykładzie Kaliningradu, Uniwersytet Kardynała Stefana Wyszyńskiego 2000. Jednakże w pracy tej opisano zaledwie część diaspory polskiej Obwodu Kaliningradzkiego FR, skupiając się głównie na kontekście religijnym zagadnienia społeczności katolickiej w Kaliningradzie. Badania nad diasporą polską w Obwodzie Kaliningradzkim FR prowadzili również inni badacze. Zob. H. Murawska, Ludność narodowości polskiej w Kaliningradzie (omówienie wyników badań socjologicznych), maszynopis w zbiorach Ośrodka Badań Naukowych im. Wojciecha Kętrzyńskiego w Olsztynie; T. Baryła, Polacy w Obwodzie Kaliningradzkim, referat wygłoszony na konferencji „Polacy w Europie Wschodniej”, Ośrodek Badań Naukowych im. Wojciecha Kętrzyńskiego, Olsztyn, 22 listopada 2005 r.; K. Jarosz, Polacy w Obwodzie Kalinin- 
Na początku warto odnieść się do kilku kwestii terminologicznych. W szczególności wyjaśnienia i doprecyzowania wymaga użyty w tytule termin „diaspora”, Najogólniej rzecz ujmując, terminem „diaspora” należy określić skupiska danej nacji żyjące w rozproszeniu wśród społeczności innego narodu, przebywające tam nie tylko w wyniku przymusu czy też konieczności, ale także wskutek dobrowolnego wyjazdu ${ }^{4}$. Należy zwrócić uwagę na dość szerokie podejście do analizowanego pojęcia przy użyciu tego określenia. Z drugiej jednak strony, niejednokrotnie kategoria diaspory przeciwstawiana była terminowi mniejszości narodowej. W tym ujęciu diaspora to społeczność napływowa, natomiast mniejszość narodowa jest grupą o charakterze autochtonicznym ${ }^{5}$. Zgodnie $\mathrm{z}$ takim podziałem uprawnionym wydaje się nazywanie diasporą Polaków zamieszkujących Obwód Kaliningradzki FR, w przeciwieństwie do np. Polaków na Litwie czy Białorusi. W takim też rozumieniu będzie ów termin używany przez autora $\mathrm{w}$ niniejszym artykule.

Zajmując się kwestią liczebności polskiej diaspory w Obwodzie Kaliningradzkim FR nie sposób pominąć problematyki jej obecności na badanym

gradzkim 1945-2010, referat wygłoszony w Ośrodku Badań Naukowych im. Wojciecha Kętrzyńskiego, Olsztyn, 14 października 2010 r. Z kolei ks. Jerzy Steckiewicz z katolickiej parafii św. Wojciecha-Adalberta w Kaliningradzie przygotowywał rozprawę doktorską na temat struktur Kościoła katolickiego w Obwodzie Kaliningradzkim FR.

3 Na popularność tego określenia zwraca uwagę Arkadiusz Żukowski w artykule Dyskurs metodologiczny nad terminem „Polonia”, w: W kraju i na wychodźstwie. Księga pamiatkowa ofiarowana Profesorowi Sławomirowi Kalembie w sześćdziesięciopięciolecie urodzin, pod red. Z. Karpusa, N. Kasparka, L. Kuka, J. Sobczaka, Toruń-Olsztyn 2001, s. 687-688. Warto zaznaczyć, iż termin „diaspora” został spopularyzowany w pierwszej kolejności w piśmiennictwie zagranicznym. Zob. R. Cohen, Global Diasporas. An Introduction, Seattle 1997; G. Sheffer, Modern Diaspora in International Politics, Londyn 1986; W. Safran, Diasporas in Modern Societies. Myth of Homeland and Return, „Diaspora” 1991, nr 1; R. Mayer, Diaspora. Eine kritische Begriffsbestimmung, Bielefeld 2005; Nacjonalnyje diaspory $w$ Rossii $i$ za rubieżom $w X I X-X X$ ww. Sbornik statjej, pod red. J. A. Poljakowa, G. J. Tarle, Moskwa 2001.

4 A. Walaszek, Polska diaspora, w: Polska diaspora, pod red. A. Walaszka, Kraków 2001, s. 8-9; A. Sadowski, Aktualny stan i zadania przyszłe badań nad Polakami na Wschodzie..., s. 53-54.

5 Taki dychotomiczny podział w odniesieniu do zbiorowości polskich w krajach byłego ZSRR zastosował Hieronim Kubiak, Polacy i Polonia w ZSRR: kwestie terminologiczne, periodyzacja, rozmieszczenie przestrzenne, szacunki ilościowe, w: Mniejszości polskie i Polonia w ZSRR..., s. 18. 
terytorium przed II wojną światową. Historia Królewca jest nierozerwalnie związana z Polakami zamieszkującymi zarówno samo miasto, jak również tereny do niego przylegające, a odpowiadające terytorium współczesnego Obwodu Kaliningradzkiego FR. Jak podaje Janusz Jasiński pierwsi polscy osadnicy zaczęli przybywać do miasta już w XIV w. W kolejnych stuleciach ich liczba wzrastała, by w połowie XVII w. osiagnąć wielkości zbliżone do 7 tys. osób, co stanowiło wówczas około 25\% ogółu mieszkańców miasta ${ }^{6}$. Królewiec był także na przestrzeni wieków żywym ośrodkiem kultury polskiej, piśmiennictwa, jak również intelektualnym centrum polskiego luteranizmu, co poświadcza spore znaczenie ludności polskojęzycznej w mieście i otaczającym go bezpośrednio obszarze. $\mathrm{Z}$ czasem liczba Polaków zamieszkujących miasto stopniowo malała, choć jeszcze w połowie XVIII w. wynosiła około 5 tys. $^{7}$, zaś Polacy zamieszkiwali nie tylko Królewiec, ale także inne miasta m.in. Welawę (obecnie Znamieńsk) i Tylżę (obecnie Sowietsk). Na przestrzeni XIX w. liczba członków polskiej społeczności w mieście zmniejszyła się znacznie, głównie wskutek nasilających się procesów planowo prowadzonego wynaradawiania, jak również naturalnej asymilacji. Wobec tego główną część królewieckiej społeczności polskiej stanowili studenci Uniwersytetu, jak również polskojęzycznego ewangelickiego seminarium duchownego ${ }^{8}$. Na początku XX w. społeczność ta w Królewcu w zasadzie zanikła. Nadal natomiast mieszkała pewna liczba ludności pochodzenia polskiego w niektórych powiatach stanowiących obecnie część Obwodu Kaliningradzkiego FR, choć w stosunkowo krótkim czasie całkowicie zanikła 9 . W dwudziestoleciu międzywojennym jedyną grupą Polaków żyjących

6 J. Jasiński, Historia Królewca. Szkice z XIII-XX stulecia, Olsztyn 1994, s. 59.

7 P. Fijałkowski, Parafia św. Mikołaja na Kamiennej Grobli w Królewcu jako centrum luteranizmu polskiego w XVIII wieku, „Komunikaty Mazursko-Warmińskie" 1997, nr 2, s. 31. Dane te dotyczą jedynie Polaków wyznania protestanckiego, jednakże ówczesna liczba Polaków-katolików była niewielka, pomimo funkcjonowania w mieście analogicznej parafii katolickiej. Zob. R. Tomkiewicz, Sesja naukowa ,Królewiec a Polska”, „Komunikaty Mazursko-Warmińskie” 1992, nr 2, s. 212.

${ }^{8}$ Jednorazowo było to około 1 tys. osób. Zob. Królewiec w oczach Polaków w XIX wieku, wybór i oprac. Z. Fras, N. Kasparek, Olsztyn 1998, s. 5; G. Jasiński, Kościót ewangelicki na Mazurach w XIX wieku (1817-1914), Olsztyn 2003, s. 136.

${ }^{9}$ M.in. na północ od obecnego Węgorzewa i Gołdapi. Szacuje się, iż była to liczba około 5 tys. osób. Zob. S. Thugutt, Polska i Polacy. Ilość i rozsiedlenie ludności polskiej, Warszawa 1915, s. 25. 
w Królewcu byli studenci Albertyny, choć ich liczba z pewnością nie przekraczała jednorazowo kilkuset osób ${ }^{10}$.

Aktualnie ludność Obwodu Kaliningradzkiego FR stanowi, zarówno pod względem pochodzenia terytorialnego, jak i przynależności narodowościowej oraz etnicznej zlepek przesiedleńców z różnych obszarów byłego Związku Radzieckiego. Skład narodowościowy społeczności Obwodu Kaliningradzkiego FR jest odzwierciedleniem różnorodności narodowościowej, etnicznej i wyznaniowej dawnego ZSRR i współczesnej Rosji ${ }^{11}$. Zgodnie z oficjalnymi statystykami urzędowymi opartymi na wynikach spisu powszechnego z 2002 r. obszar prowincji zamieszkuje około 110 narodowości, wśród których najwięcej jest Rosjan - 786,9 tys., Białorusinów - 50,7 tys., Ukraińców - 47,2 tys., Litwinów - 13,9 tys., Ormian $-8,4$ tys., Niemców $-8,3$ tys. oraz Tatarów $-4,7$ tys. Zgodnie z wynikami spisu z 2002 r. na terenie Obwodu Kaliningradzkiego FR mieszkało 3,9 tys. Polaków ${ }^{12}$.

Należy jednak podejrzewać, że liczba ta jest w pewnym stopniu niedoszacowana. Jak bowiem wskazują wyniki analogicznych badań przeprowadzanych w innych krajach, nie dają one miarodajnych informacji w odniesieniu do narodowości respondentów: część z badanych członków mniejszości narodowych i etnicznych przyznaje się do narodowości reprezentowanej przez większość. Drugim ważnym czynnikiem jest fakt, iż w czasach Związku Radzieckiego głoszono indyferentyzm narodowy jako oficjalną ideologię państwową, zastępując poczucie przynależności narodowej wzorem sowietskogo czełowieka, stanowiącym swego rodzaju wygodny substytut jednoznacznych deklaracji narodowościowych ${ }^{13}$.

W celu określenia przybliżonej faktycznej liczby członków diaspory polskiej w Obwodzie Kaliningradzkim FR należy przeanalizować proces przesiedlania do Obwodu ludności z innych obszarów byłego Związku Radzieckiego. Powojenna historia polskiej diaspory w Obwodzie Kaliningradzkim Rosyjskiej Federacyjnej Socjalistycznej Republiki Radzieckiej

10 A. Skrobacki, Polacy na Wydziale Lekarskim Uniwersytetu w Królewcu, Olsztyn 1969, s. 43.

11 V. Martynuk, The role of interethnic factor in the development of the Kaliningrad region, „ECMI Report” 2003, nr 50, s. 4-7.

12 Wsierosijskaja pieriepis' nasielienia 2002 goda, t. 4: Nacjonalnyj sostaw $i$ władenie jazykami, grazdanstwo, http://www.perepis2002.ru/index.html?id=17, 5.05.2006.

13 A. Karpenko, Regionalization and identity. The subiectivity of Kaliningrad, „UNISCI Discussion Papers” 2006, nr 10, s. 284. 
(RFSRR), a od 1991 r. Federacji Rosyjskiej związana jest ze znacznymi przeobrażeniami demograficznymi, jakie obszar ten przeszedł po zakończeniu II wojny światowej. Spośród wielu wspomnianych grup przesiedleńców przybywających do Obwodu w latach 1945-1953 należy przyjrzeć się w szczególności kilku ${ }^{14}$.

Jedną z nich byli mieszkańcy obwodów Litewskiej SRR, Ukraińskiej SRR i Białoruskiej SRR. Najwięcej przesiedleńców, wśród których pewną część mogli stanowić Polacy, przybyło z terenów Białorusi ${ }^{15}$. W latach 1947-1950, czyli w okresie, gdy migracje będące rezultatem planowo prowadzonych akcji szczególnie przybrały na sile, liczby odnoszące się do przybywającej ludności kształtowały się następująco:

a) z terytorium Białoruskiej SRR przesiedlono 35,2 tys. osób, z czego 7,6 tys. wyjechało z Obwodu Kaliningradzkiego, zaś 27,6 tys. w nim pozostało;

b) z terytorium Ukraińskiej SRR przybyło 29,2 tys. osób, z czego 11,7 tys. opuściło Obwód Kaliningradzki, zaś 17,6 tys. pozostało na miejscu przesiedlenia;

c) z terytorium Litewskiej SRR przyjechało 15,1 tys. osób, spośród których 6,2 tys. wyjechało z Obwodu Kaliningradzkiego, zaś 8,9 tys. pozostało na miejscu ${ }^{16}$.

14 Najpełniej poszczególne grupy opisuje Olga Stiepanowa w artykule Zasiedlenie obwodu kaliningradzkiego w pierwszych latach po II wojnie światowej, „Komunikaty Mazursko-Warmińskie" 1996, nr 2, s. 193-200 oraz Jurij Kostiaszow, Zasielenije Kaliningradskoj obłasti posle wtoroj mirowoj wojny, w: Gumanitarnaja nauka w Rossii. Sorosowskije laureaty. Istorija, archeołogija, kulturnaja antropotogija i etnografia, Moskwa 1996, s. 82-84.

15 W. P. Mamiejukow, Organizacija pieriesieleniaja kołchoznikow i rabotnikow sowchozow iz Biełorussii w Kaliningradskuju obłast' $w$ dokumientach Nacyonalnogo Archiwa Riespubliki Biełarus', w: Kaliningradskije archiwy. Materijaty i issledowanija. Naucznyj sbornik, wyd. 6, pod red. W. N. Masłowa, Kaliningrad 2003, s. 69-76. Zob. zestawienie statystyczne Wydziału Przesiedleń i Repatriacji Rady Ministrów Białoruskiej SRR dotyczące przebiegu przesiedlania kołchoźników z BSRR do Obwodu Kaliningradzkiego RFSRR przedstawione w opracowaniu Samaja zapadnaja. Sbornik dokumientow $i$ materijałow o stanowlienii i razwitii Kaliningradskoj obłasti, oprac. W. M. Arnautowicz, A. I. Klimowa, E. M. Kołganowa i in., Kaliningrad 1980, s. 40.

${ }^{16}$ G. W. Krietinin, W. N. Briuszinkin, W. I. Galcow i in., Oczerki isstorii Wostocznoj Prussii, Kaliningrad 2002, s. 474. Zbliżone dane liczbowe dotyczące przesiedleń w latach 1948-1950 przytacza J. W. Kostiaszow, Zasielenije Kaliningradskoj obłasti posle wtoroj mirowoj wojny..., s. 86. 
Z terenów trzech wymienionych republik do Obwodu Kaliningradzkiego RFSRR przybyło łącznie około 79,5 tys. ludności. Choć, jak pokazują przytoczone dane liczbowe, znaczna ich część nie osiedliła się na dłużej, to jednak ponad 54 tys. osób pozostało w Obwodzie Kaliningradzkim RFSRR ${ }^{17}$. Ze względu na fakt, iż zarówno przed II wojną światową, jak i po jej zakończeniu tereny te zamieszkałe były przez dużą liczebnie społeczność polską należy przypuszczać, iż pewna część przesiedleńców mogła deklarować jeśli nawet nie polską narodowość, to przynajmniej polskie pochodzenie i mniej lub bardziej świadomie je kultywować.

Po 1953 r. procesy związane zarówno z planowo prowadzonymi przesiedleniami do Obwodu Kaliningradzkiego RFSRR, jak i wyjazdami powrotnymi ulegały stopniowemu wygaszeniu ${ }^{18}$. Szczegółowych danych na temat liczebności migracji i obszarów pochodzenia przybywającej ludności dostarczają statystyki kaliningradzkiego Obwodowego Urzędu Statystycznego. Zawarto $\mathrm{w}$ nich dokładne liczby ludności z podziałem na republiki, z których przybyli. Z Litewskiej SRR do 1953 r. przybyło i osiedliło się na stałe ponad 16 tys. ludzi, z Białoruskiej SRR - około 36,2 tys. ludzi, zaś z Ukraińskiej SRR - ponad 19 tys. ${ }^{19}$ Zarazem trudno jest określić, jaką część tej grupy stanowili obywatele pochodzenia polskiego, choć mogła to być liczba około kilku tysięcy osób. Należy jednak przypuszczać, że w nowych warunkach, w oderwaniu od lokalnych małych ojczyzn znaczna część tej ludności szybko traciła kontakt z polską tradycją, asymilując się z rosyjską większością. Mimo to, właśnie potomkowie byłych imigrantów z terenów Litwy, Białorusi i Ukrainy stanowią współcześnie główny trzon diaspory polskiej w Obwodzie ${ }^{20}$.

Drugą istotną grupa, będącą potencjalnym ,źródłem” diaspory polskiej w Obwodzie Kaliningradzkim FR mogli być wspomniani wcześniej

17 T. Baryła, Wstęp, w: Przesiedleńcy opowiadaja. Pierwsze lata Obwodu Kaliningradzkiego we wspomnieniach i dokumentach, pod red. J. W. Kostjaszowa, Olsztyn 2000, s. 20.

18 J. Kostiaszow, Obratniczestwo $w$ processie zasielenija Kaliningradskoj oblasti w poslewojennyje gody, w: Battijskij region w istorii Rossii i Jewropy, pod red. W. I. Galcowa, Kaliningrad 2005, s. 212-213.

19 E. A. Masłow, Zasielenije Kaliningradskoj obłasti i formirowanije religioznoj struktury jejo nasielenija, w: Battijskije issledowanija. Sbornik naucznych trudow, Kaliningrad 2002, s. 29.

20 H. Murawska, Polacy $w$ Kaliningradzie, „Borussia” 1997, nr 15, s. 261-262; taż, Ludność narodowości polskiej w Kaliningradzie..., s. 3; J. Kurski, Pożqdanie w cieniu armat, „Gazeta Wyborcza” 1993, nr 302, s. 10. 
jeńcy wojenni i robotnicy przymusowi pracujący w północnej części Prus Wschodnich w trakcie wojny. W końcowym etapie wojny ich liczba wynosiła około 240 tys. ${ }^{21}$ Więzienia, obozy i różnego rodzaju miejsca odosobnienia skupiające jeńców w północnej części dawnych Prus Wschodnich znajdowały się w Kaliningradzie, Czerniachowsku, Gwardiejsku, Bagrationowsku, Sowietsku i Zielonogradsku ${ }^{22}$. Po ustaniu działań wojennych przystappiono do weryfikacji jeńców i więźniów niemieckich obozów koncentracyjnych pod kątem możliwości osiedlenia się w Obwodzie Kaliningradzkim. Pozytywnie weryfikację przeszło około 17 tys. byłych więźniów ${ }^{23}$. Z pewnością sporą ich część stanowili Polacy. Mogła to być liczba kilku tysięcy. Wskazuje na to fakt, iż już w kwietniu 1945 r. ludność polska rekrutująca się z dawnych więźniów przystąpiła do próby utworzenia w Królewcu Rady Miejskiej i organizacji Straży Obywatelskiej $^{24}$. Należy jednak uwzględnić, iż większość z nich pomimo przejścia pozytywnej weryfikacji w latach późniejszych wyjechała do Polski.

Ludność pochodzenia polskiego mogła występować także wśród innych grup osiedlających się na opisywanym obszarze tuż po wojnie, m.in. wśród specjalistów potrzebnych po ustaniu działań wojennych do odbudowy i uruchamiania zrujnowanych zakładów przemysłowych. Grupy specjalistów i wykwalifikowanych robotników zaczęły przybywać do Królewca już latem 1945 r. Początkowo były to starannie wyselekcjonowane grupy inżynierów z Rosyjskiej FSRR ${ }^{25}$. Od czerwca 1946 r., kiedy to rząd Związku Radzieckiego przyjął postanowienie „O przedsięwzięciach ustroju gospodarczego obwodu königsbergskiego" nasilił się napływ kadr inżynieryjnych i specjalistów z innych obszarów ZSRR ${ }^{26}$. Jak podają różnorodne źródła, przekazy i opowiadania przesiedleńców, wśród

21 B. Koziełło-Poklewski, Zagraniczni robotnicy przymusowi w Prusach Wschodnich w latach II wojny światowej, Warszawa 1977, s. 108; J. W. Kostiaszow, Zasielenije Kaliningradskoj obłasti posle wtoroj mirowoj wojny..., s. 84.

22 O. Stiepanowa, Zasiedlanie obwodu kaliningradzkiego $w$ pierwszych latach po II wojnie światowej..., s. 196.

23 T. Baryła, Wstęp..., s. 18.

24 J. Jasiński, Historia Królewca ..., s. 265; M. A. Koprowski, Królewiec - Königsberg - Kaliningrad, „Sycyna” 1997, nr 59, s. 6.

25 W. Galcow, Obwód Kaliningradzki w latach 1945-1991. Społeczeństwo, gospodarka, kultura, „Komunikaty Mazursko-Warmińskie” 1996, nr 2, s. 207.

26 O. Stiepanowa, Zasiedlanie obwodu kaliningradzkiego $w$ pierwszych latach po II wojnie światowej..., s. 194. 
kadr specjalistycznych przybywających w owym czasie do Obwodu Kaliningradzkiego RFSRR znajdowali się również Polacy ${ }^{27}$.

Nie należy zapominać o pewnej - nieznacznej, co prawda - liczbie Polaków, którzy bezpośrednio po zaprzestaniu działań wojennych osiedlili się w powiatach położonych na południe od Pregoły (świętomiejskim, iławeckim, gierdawskim, darkiejmskim, północnej części bartoszyckiego i gołdapskiego), kiedy liczono, że zostaną one włączone w całości do Polski, zgodnie z przedwojennym podziałem administracyjnym ${ }^{28}$. Szacunkowo można jednak uznać, iż liczba Polaków w obu grupach była niewielka, sięgająca najwyżej kilkuset osób ${ }^{29}$.

Wpływ na liczebność diaspory polskiej miało również ogólne poluźnienie represyjności radzieckiego, a później rosyjskiego aparatu państwowego, co sprzyjało deklarowaniu się mieszkańców Obwodu Kaliningradzkiego FR pod względem przynależności narodowej. Dochodziła do tego chęć odnawiania i kultywowania tradycji narodowej wśród ludności pochodzenia polskiego. Z pewnością czynnikiem sprzyjającym było ocieplenie stosunków polsko-rosyjskich na początku lat 90 . i związany z tym wzrost sympatii propolskich $\mathrm{w}$ społeczeństwie rosyjskim ${ }^{30}$. Poza tym, na integrację polskiej społeczności wpływało powstanie w Kaliningradzie polskiej parafii rzymsko-katolickiej, co nastąpiło w 1992 r. ${ }^{31}$ Pewna część ludności pochodzenia polskiego decydowała się wówczas na deklarowanie polskiej narodowości w paszportach. Zgodnie, bowiem, z danymi Wydziału Ewidencji Ludności Kaliningradu w 1995 r. wpis w paszporcie wewnętrznym dotyczący narodowości polskiej posiadało 1983 miesz-

27 Zob. seria artykułów Kleofasa Lawrynowicza Polacy Obwodu Kaliningradzkiego - Królewieckiego, publikowanych od stycznia 2005 r. na łamach „Głosu znad Pregoły”, miesięcznika wydawanego przez Wspólnotę Kultury Polskiej w Kaliningradzie.

28 E. Wojnowski, Zarys przemian na Warmii i Mazurach $w$ okresie trzydziestolecia władzy ludowej, w: Dzieje Warmii i Mazur w zarysie: Od 1871 do 1975 roku, pod red. T. Filipkowskiego, t. 2, Olsztyn 1983, s. 198; Istorija rosijsko-polskoj granicy, „Bałtijskij Ałmanach”, nr 3, http://www.klgd.ru/ru/city/750/almanac/a3_16.php, 10.04.2006 r.

29 J. Kurski, Pożadanie w cieniu armat..., s. 10.

30 K. Żęgota, Władze polskie wobec zbiorowości polonijnej w Obwodzie Kaliningradzkim Federacji Rosyjskiej, w: Polska a Obwód Kaliningradzki Federacji Rosyjskiej. Teraźniejszość i wyzwania przyszłości, pod red. A. Żukowskiego, Toruń 2008, s. 219-220.

31 http://www.adalbert.internet.pl/index1.html, 3.05.2006 r. 
kańców Kaliningradu, zaś w całym Obwodzie Kaliningradzkim FR takich osób było $4550^{32}$.

Trzecim istotnym czynnikiem wpływającym na obecną liczebność i rozmieszczenie przestrzenne polskiej diaspory było osiedlanie się obywateli Kazachstanu pochodzenia polskiego w Obwodzie Kaliningradzkim FR, głównie w jego południowych częściach: w Oziersku, w pobliżu osiedla Żelieznodorożnyj i Czerniachowska. Od początku lat 90. do Obwodu Kaliningradzkiego FR przybyło, wedle różnych szacunków, od 37 do ponad 120 tys. mieszkańców Kazachstanu ${ }^{33}$. Jak pokazują wyniki badań, tendencje w zakresie osiedlania się obywateli Kazachstanu w Obwodzie Kaliningradzkim FR są spadkowe, zwłaszcza od drugiej połowy lat 90. Mimo to, emigranci ci są obecnie dość istotnym komponentem demograficznym enklawy, stanowiąc - wedle różnych obliczeń - od 7 do $11 \%$ jej mieszańców ${ }^{34}$. Trudno jest określić jaką część z nich stanowią Polacy, choć ich łączną liczbę można ostrożnie oszacować na 300 do 500 osób ${ }^{35}$.

Trudności w określeniu liczebności diaspory polskiej w Obwodzie Kaliningradzkim FR związane są nie tylko z dość szczupłą bazą źródłową. Należy wątpić czy takie precyzyjne wyliczenie jest w ogóle możliwe do zrealizowania. Na taki stan rzeczy ma z pewnością wpływ brak możliwości określenia dokładnych i obiektywnych cech przynależności narodowej badanej grupy, a przynajmniej brak możliwości określenia

32 H. Murawska, Polacy w Kaliningradzie..., s. 261.

33 Kazachowie w Kaliningradzie. Nazywaja ich ,, mafia”. Kim oni sq w rzeczywistości?, „Obwód Kaliningradzki. Przegląd faktów, wydarzeń, opinii” 2001, nr 2, s. 13. Różnice w szacunkach wynikają z uwzględniania w obliczeniach tylko legalnych imigrantów, bądź też zawierania w liczbach także migracji nielegalnych. Zob. C. Wellmann, Historische Miszelle. Die russische Exklave Kaliningrad als Konfliktsyndrom, „Die Friedens-Warte Journal of International Peace and Organization” 2000, $\mathrm{nr}$ 3-4, s. 399; P. Järve, National-cultural autonomie and interethnic relations In the Kaliningrad oblast, „ECMI Report” 2002, nr 30, s. 8; A. Skarzinskaite, Migration and forced migration in the Kaliningrad oblast of Russia, „ECMI Report” 2001, nr 11, s. 3.

${ }^{34}$ V. Tishkov, Z. Zayinchkovskaya, G. Vitkovskaya, Migration in the countries of the former Soviet Union. A paper prepared for the Policy Analysis and Research Programme of the Global Commission on International Migration, 2005, www.gcim.org/attachements/RS3.pdf, 11.05.2006 r.

35 R. Daszczyński, M. Wąs, Uciec jak najblizej, „Gazeta Wyborcza” 2000, nr 15, s. 18; S. Galicki, O naturze polskiej i o duchowości Polaków - przesiedlonych do Kazachstanu, „Głos Znad Pregoły” 2003, nr 5, s. 7. 
wagi każdej z tych cech przy deklaracjach narodowych ${ }^{36}$. Większość badaczy do zespołu najistotniejszych cech identyfikacji narodowej zalicza: pochodzenie genealogiczne, wyznanie, autoidentyfikację, znajomość języka i kultury narodowej oraz zapisy dotyczące narodowości w różnego rodzaju dokumentach tożsamości ${ }^{37}$. Jednak bez zbytniego wgłębiania się w to zagadnienie należy stwierdzić, iż w przypadku badania liczebności polskiej diaspory w Obwodzie Kaliningradzkim FR poszczególne obliczenia dają różne wyniki w zależności od przyjętych założeń metodologicznych. Dość powiedzieć, że zgodnie z wynikami spisu powszechnego, przeprowadzonego w 1989 r. prawie 86\% respondentów przyznających się do polskości uznało za swój ojczysty język inny niż polski ${ }^{38}$. Poza tym, warto zwrócić uwagę na znaczne - jeszcze do niedawna silnie oddziałujące - ograniczenia jeśli chodzi o możliwość deklarowania innej niż rosyjska narodowości mieszkańców Obwodu Kaliningradzkiego, obrazujące się we wspomnianym wzorcu sowietskogo czełowieka ${ }^{39}$.

Czynniki te implikują znaczne różnice w określaniu wielkości polskiej diaspory w Obwodzie Kaliningradzkim FR w zależności od źródła informacji. Największą liczbę członków polskiej diaspory podają źródła opierające się na szacunkach przedstawianych przez samych Polaków z Obwodu Kaliningradzkiego FR lub publicystów zajmujących się tą problematyką. Z drugiej strony, niepełne i okrojone dane zawarte są w wynikach spisów powszechnych przeprowadzanych w b. Związku Radzieckim i w Rosji. Szacunki najbliższe stanowi faktycznemu oparte na liczbie i rozmieszczeniu polskich organizacji kulturalnych i religijnych przedstawiane są przez pracowników Konsulatu Generalnego RP w Kaliningradzie oraz polskich duchownych pracujących w Obwodzie Kaliningradzkim FR. Mało przydatne są natomiast dane polskiego Głównego Urzędu Statystycznego na temat migracji z Polski do Rosji i odwrotnym kierunku

36 Zwraca na to uwage Oleg Gorbaniuk w artykule Czynniki konstytuujace samookreślenie się narodowe w opinii młodzieży polskiego pochodzenia ze wschodu studiujacej w Polsce, „Przegląd Polonijny” 1998, z. 3, s. 75-76. Choć badania te dotyczyły głównie ludzi młodych pochodzących z Ukrainy i Białorusi, to jednak ich wyniki mogą być miarodajne także dla diaspory polskiej w Obwodzie Kaliningradzkim FR.

37 Ibidem, s. 77; A. Sadowski, Aktualny stan i zadania przyszłe badań nad Polakami na Wschodzie..., s. 50.

38 N. A. Dubowa, N. A. Łopulenko, M. J. Martinowa, Kaliningradskaja obłast: sowremiennyje etnokulturnyje pocessy, Moskwa 1998, s. 13.

39 A. Karpenko, Regionalisation and identity..., s. 284. 
- po pierwsze, stanowią one ułamek ruchów migracyjnych do i z Polski, po drugie zaś, w statystykach tych nie wyodrębniono migracji dotyczących Obwodu Kaliningradzkiego FR ${ }^{40}$.

W pierwszej kolejności warto przeanalizować dane pochodzące ze spisu powszechnego, jaki został przeprowadzony w Federacji Rosyjskiej w 2002 r. $^{41}$ Zgodnie z jego wynikami, na terytorium Obwodu Kaliningradzkiego FR zamieszkiwało nieco ponad 3,9 tys. osób określających swą narodowość jako polską ${ }^{42}$. Ze względu na specyficzny charakter badań, jakimi są spisy powszechne należy uznać, że jest to liczba zaniżona. Wskazują na to choćby wyniki ostatniego spisu powszechnego w Polsce, kiedy to ubytki w liczbie przedstawicieli mniejszości narodowych, w porównaniu z poprzednimi spisami, nie dały się wytłumaczyć procesami związanymi z migracją przestrzenną, bądź ruchem naturalnym. Choć specyfika obu spisów była niewątpliwie różna, to jednak prawdziwy wydaje się wniosek, iż tego typu badania podają zaniżone liczby dotyczące wielkości mniejszości narodowych.

W tym miejscu należy odwołać się do wyników poprzednich spisów powszechnych przeprowadzanych w byłym Związku Radzieckim. Ich wyniki pokazują, iż liczba osób podających narodowość polską zmieniała się w dość specyficzny sposób. Warto podkreślić, że spisy powszechne w Związku Radzieckim były przeprowadzane w dość regularnych odstępach czasowych, tj. w przybliżeniu co dziesięć lat. Można zatem prześledzić zmiany w zakresie deklaracji narodowościowych mieszkańców Obwodu Kaliningradzkiego. I tak, zgodnie $\mathrm{z}$ wynikami spisu powszechnego z 1959 r. - czyli w czasie, gdy ustały już regularne ruchy przesiedleńcze - na terenie Obwodu zamieszkiwało niespełna 3,3 tys. osób deklarujących narodowość polską ${ }^{43}$. Jedenaście lat później podobną deklarację złożyło

40 Tabl. 43. Emigranci przebywajacy za granica czasowo powyżej 2 miesięcy wedtug czasu przebywania oraz płci i kraju przebywania, w: Migracje zagraniczne ludności 2002, pod red. T. Toczyńskiego, Warszawa 2003, s. 184.

41 Dane dotyczące ludności Obwodu Kaliningradzkiego FR objęte spisem powszechnym przeprowadzonym w 2010 r. zostaną opublikowane w 2011 r. Zob. http://www.perepis-2010.ru/, 14.11.2010 r.

42 Wsierosijskaja pieriepis' nasielienia 2002 goda, t. 4: Nacjonalnyj sostaw $i$ władenie jazykami, grażdanstwo, http://www.perepis2002.ru/index.html?id=17, $5.05 .2006 \mathrm{r}$.

43 Wsjerosijskaja pieriepis' nasielienia 1959 goda. Nacjonalnyj sostaw nasielienija po regionam Rossii, http://demoscope.ru/weekly/ssp/rus_nac_59.php?reg=29, 27.04.2006 r. 
już nieco ponad 4 tys. osób ${ }^{44}$. Stały wzrost liczby ludności identyfikującej się z polskością wykazały także kolejne spisy przeprowadzone w $1979 \mathrm{r}$. oraz 1989 r. Wtedy to narodowość polską zadeklarowało około 4,2 tys. osób $^{45}$.

Jednocześnie w wynikach ostatniego spisu z 2002 r. odnotowano wspomniane już, zauważalne ubytki w liczbie ludności deklarującej polską przynależność narodową. Jak zatem widać, liczba osób przyznających się do polskości zmieniała się na przestrzeni powojennych lat w zauważalny sposób i - co jest najistotniejsze z punktu widzenia określenia liczebności polskiej diaspory - owo „falowanie” nie da się uzasadnić innymi danymi demograficznymi pochodzącymi z analogicznego okresu. Mianowicie, po 1945 r. w Obwodzie Kaliningradzkim RFSRR występował stały systematyczny wzrost liczby ludności, powodowany zarówno ruchami migracyjnymi, jak również przyrostem naturalnym ${ }^{46}$. Zatem - jak widać - co najmniej problematyczne wydają się $\mathrm{w}$ tym świetle wyniki spisu powszechnego z 2002 r. Wobec tego, chcąc ustalić przybliżoną liczebność polskiej diaspory w Obwodzie Kaliningradzkim FR należy odwołać się do danych szacunkowych.

Oficjalne, choć szacunkowe, dane statystyczne określają wielkość polskiej diaspory na 4,5 do 5 tys. osób ${ }^{47}$. Minimalne, z pewnością, szacunki sporządzane na podstawie wpisów w dowodach tożsamości w rubryce dotyczącej narodowości mówią o 4,6 tys. osobach narodowości

44 Wsjerosijskaja pieriepis' nasielienia 1970 goda. Nacjonalnyj sostaw nasielienija po regionam Rossii, http://demoscope.ru/weekly/ssp/rus_nac_70.php?reg=7, 27.04.2006 r.

45 Wsjerosijskaja pierepis' nasielienia 1979 goda. Nacjonalnyj sostaw nasielienija po regionam Rossii, http://demoscope.ru/weekly/ssp/rus_nac_79.php?reg=7, 27.04.2006 r. W tym samym czasie liczba członków polskiej diaspory w samym mieście wzrosła z 1,7 tys. do 1,9 tys. osób. Naliczije nasielenija goroda Kaliningrada w 1996 godu. Statisticzeskij sbornik, Kaliningrad 1997, s. 5.

46 W. Galcow, Obwód Kaliningradzki w latach 1945-1991 ..., s. 208-209. Opisane procesy związane ze wzrostem ogólnej liczby mieszkańców przy jednoczesnych sinusoidalnych zmianach liczby ludności polskiej odnoszą się do całego obszaru dawnego Związku Radzieckiego. Zob. A. Płatek, Polska diaspora w Rosji Radzieckiej i Zwiazku Socjalistycznych Republik Radzieckich, w: Polska diaspora, pod red. A. Walaszka, Kraków 2001, s. 308.

47 Dane Obwodowego Urzędu Statystycznego w Kaliningradzie uzyskane w rozmowie telefonicznej z Markiem Juzepczukiem, Wicekonsulem ds. Polonii Konsulatu Generalnego RP w Kaliningradzie, przeprowadzonej przez autora 2 marca $2006 \mathrm{r}$. 
polskiej $^{48}$. Podobnie zaniżone wydają się też obliczenia badaczy rosyjskich. Według nich ogólna liczba członków polskiej diaspory nie przekracza 3,5-3,7 tys. ${ }^{49}$ Zapewne wpływ na takie wyniki ma sztywne trzymanie się wspomnianych wskaźników narodowości deklarowanych w trakcie spisu powszechnego z 2002 r. oraz informacji zawartych w dowodach tożsamości, a nie oddających przecież stanu faktycznego - przed $1991 \mathrm{r}$. częste było przymusowe wpisywanie narodowości rosyjskiej bądź białoruskiej ${ }^{50}$.

Istotne wydają się też dane przedstawiane przez Agnieszkę Abramowicz i Jerzego Sukowa, polskich nauczycieli pracujących w Kaliningradzie. W 2000 r. oceniali oni liczbę Polaków w całym Obwodzie na ok. 6 tys., podając jednocześnie liczbę 20 tys. jako ludności pochodzenia polskiego $^{51}$. Zbliżone dane przedstawiają pracownicy Konsulatu Generalnego RP w Kaliningradzie. Wicekonsul Andrzej Opaliński pod koniec 2004 r. szacował liczbę osób związanych z polskością na około 7 do 10 tys. ${ }^{52}$

Informacji w tej kwestii mogą też dostarczyć szacunkowe dane prezentowane przez struktury Kościoła katolickiego działającego na terenie Obwodu Kaliningradzkiego FR. Na marginesie warto zauważyć, iż ogólna liczba katolików w Obwodzie Kaliningradzkim FR oscyluje wokół 30 tys. Informacje te są jednak mało użyteczne z punktu widzenia liczebności polskiej diaspory, gdyż - poza Polakami - w skład tutejszej społeczności katolickiej wchodzą również Litwini, Białorusini i przedstawiciele innych narodowości ${ }^{53}$. Wedle nieoficjalnych danych pochodzących z parafii katolickich, liczba Polaków na badanym terenie oscyluje wokół 10 tys. ${ }^{54}$

48 We wspomnianych wcześniej, przytaczanych przez Halinę Murawską danych Wydziału Ewidencji Ludności administracji obwodowej pochodzących z 1995 r. jest mowa o 4550 osobach przyznających się do polskości. H. Murawska, Polacy w Kaliningradzie..., s. 261.

${ }^{49}$ W. Galcow, Obwód Kaliningradzki w latach 1945-1991 ..., s. 210; O. Stiepanowa, Zasiedlanie obwodu kaliningradzkiego $w$ pierwszych latach po II wojnie światowej..., s. 199.

50 M. Sandecki, Kaliningrad - miasto kulturalnej wojny, „Gazeta Wyborcza” (Trójmiasto) 2000, nr 303, s. 8.

51 Czujemy się bezpiecznie. Rozmowa z Agnieszka Abramowicz i Jerzym Sukowem, rozmawiał G. Szaro, „Gazeta Wyborcza” (Trójmiasto) 2000, nr 32, s. 5.

52 Taka bliska Polska, ,Obwód Kaliningradzki. Przegląd faktów, wydarzeń, opinii" 2004, nr 12, s. 75.

${ }^{53}$ Panorama kulturnoj żyzni regionow Rossii w sieti Internet. Kaliningradskaja obłast', Moskwa 2004, s. 59-60.

54 Dane uzyskane w rozmowie telefonicznej z wicekonsulem ds. Polonii w Konsulacie Generalnym RP w Kaliningradzie Markiem Juzepczukiem, 2.03.2006. 
Informacji w tym zakresie, choć z pewnością nieweryfikowanych, mogą też dostarczyć szacunki ks. Jerzego Steckiewicza z parafii św. Wojciecha-Adalberta w Kaliningradzie, który ocenia łączną liczbę osób pochodzenia polskiego na 20 tys. Liczba ta obejmuje zarówno Polaków świadomych swej narodowości i pochodzenia, jak i tych, którzy zostali zasymilowa$\mathrm{ni}^{55}$. Mało użyteczne są również dane dotyczące liczby wniosków o wydanie Karty Polaka złożonych w Konsulacie Generalnym RP w Kaliningradzie. Zgodnie z danymi liczbowymi Konsulatu, do marca 2009 r. złożono jedynie około 350 wniosków o wydanie Karty Polaka ${ }^{56}$.

W licznych publikacjach prasowych oraz artykułach naukowych o tematyce nie związanej bezpośrednio ze składem narodowościowym Obwodu Kaliningradzkiego FR podawane są różne często dość wysokie liczby opisujące wielkość polskiej diaspory w Obwodzie Kaliningradzkim FR. Faktem jest zarazem, iż wiarygodność tych informacji jest w praktyce niemożliwa do zweryfikowania. Najczęściej podawaną minimalną wielkością jest 3,9 tys., zaś maksymalną - $12-20$ tys. ${ }^{57} \mathrm{~W}$ analogicznych publikacjach rosyjskojęzycznych zazwyczaj uwzględniane są oficjalne dane mówiące o około 4-5 tys. członków diaspory polskiej w Obwodzie Kaliningradzkim FR $^{58}$.

Podsumowując, należy stwierdzić, iż precyzyjne określenie liczby członków diaspory polskiej zamieszkałych w Obwodzie Kaliningradzkim Federacji Rosyjskiej nie jest z pewnością do końca możliwe. Wpływ na taką sytuację mają mało dokładne i niecałościowe dane statystyczne przedstawiane przez administrację obwodową ${ }^{59}$. Jak w przypadku każdej w zasadzie społeczności polskiej mieszkającej poza krajem, szacunkowe

55 [wr], Dzieci Polonii do komunii po kolonii, „Gazeta Wyborcza” 1992, nr 182, s. 3.

56 Rozmowa z Dariuszem Kozłowskim, Wicekonsulem ds. Polonii Konsulatu Generalnego RP w Kaliningradzie, przeprowadzona przez autora w Kaliningradzie 30 marca 2009 r.

57 I. Szirkowiec, Polska diaspora $w$ obwodzie kaliningradzkim, „Wspólnota Polska" 2002, nr 1, s. 45; M. Szymański, Potencjat militarny w Obwodzie Kaliningradzkim a bezpieczeństwo Polski, „Przegląd Zachodni” 1999, nr 1, s. 141; Informator ,Flota Battycka FR”, Gdynia 1997, s. 19; M. Kowalski, Königsberg, Gebiet von [Kaliningradskaja oblast'], w: Ethnisches Bewusstsein in Mittel- und Südosteuropa um 2000. Begleittext zum Kartenblatt im Atlas Ost- und Südosteuropa, oprac. P. Jordan, K. Kocsis, P. Eberhardt, Berlin-Sztutgart 2006, s. 31.

58 Panorama kulturnoj żyzni regionow Rossii w sieti Internet. Kaliningradskaja obłast'..., s. 26.

59 W. Galcow, Obwód Kaliningradzki w latach 1945-1991 ..., s. 209. 
dane na temat wielkości tejże społeczności charakteryzują się dość dużą rozpiętością. Najbardziej optymistyczne obliczenia mówią o około 20 tysięcznej diasporze polskiej. Z drugiej strony, opierając się na „sztywnych", ale z pewnością niedoszacowanych danych oficjalnych można mówić o wielkościach rzędu niespełna 5 tys. Najbliższe prawdzie wydają się deklaracje miejscowych działaczy diasporowych, mówiące o około 7 tys. osób polskiego pochodzenia mieszkających w regionie ${ }^{60}$. Faktem jest zarazem, że problematyka przynależności narodowej związana jest z często subiektywnie pojmowaną tożsamością etniczną poszczególnych mieszkańców omawianego obszaru. Zatem nawet fakt istnienia pewnych związków z polskością wcale nie musi się przekładać w prosty sposób na ukształtowaną polską tożsamość narodową, a tym bardziej chęć jej deklarowania.

\section{The Size of Polish Minority in the Kaliningrad Oblast of the Russian Federation. An Outline of the Subject}

\section{Summary}

The issues related to Polish minority in the countries of the former Soviet Union have been intensively studied, especially since the early 1990s. It is however impossible to determine a precise number of the members of Polish minority residing in the Kaliningrad Oblast of the Russian Federation. This results from the imprecise and incomplete data presented by the local administration. The most optimistic statistics estimate Polish minority at approximately 20,000 people. On the other hand, when one refers to the 'strict' but certainly underestimated official data a number of nearly 5,000 is mentioned. Additionally, the issue of national affiliation is frequently related to the subjective perception of ethnic identity by the residents of the territory in question. Therefore, even though some Polish ties do exist, they do not necessarily translate directly into a mature Polish national identity, let alone the intention to admit such identity.

60 Rozmowa z Heleną Rogaczykową, kierującą Wspólnotą Kultury Polskiej w Kaliningradzie, przeprowadzona przez autora w Kaliningradzie 2 czerwca 2009 r. 
